\title{
Ruth Mott Foundation Gilkey Creek Relocation and Restoration Methods
}

\section{Firm Liaisons:}

Kristi Gilbert

Marketing Manager

JJR

Neal Billetdeaux

Principal

JJR

This case study was produced in 2010 as part of the Landscape Architecture Foundation's Landscape Performance Series pilot. Firms submitted their projects, and LAF staff worked with firm representatives to document the project and its environmental, social, and economic benefits.

To cite:

Landscape Architecture Foundation. "Ruth Mott Foundation Gilkey Creek Relocation and Restoration." Landscape Performance Series. Landscape Architecture Foundation, 2010. https://doi.org/10.31353/cs1451

The full case study can be found at: https://landscapeperformance.org/case-study-briefs/gilkey-creek-restoration 


\section{Ruth Mott Foundation Gilkey Creek Relocation and Restoration Methodology for Landscape Performance Benefits}

\section{- Manages all stormwater runoff generated on-site by converting $22 \%$ of the project area to green space and low-mow turf and incorporating a variety of stormwater management features.}

These numbers reflect the conversion of paved surfaces to green areas and added stormwater features. There were no actual calculations performed to verify the actual percentage. The $22 \%$ is the percentage of the project area that was converted from paved surfaces to native landscapes and low-mow turf areas. These paved areas were located over sandy, free-draining soils and much of the runoff now infiltrates into the soil. In two locations, stormwater features were constructed as wetland habitat.

One feature (1/2 acre wetland) was sized and graded to capture runoff for a first flush storm event (1" rainfall) for a 6-acre parking lot. A second feature was constructed as a habitat pond and contains a restricted outlet pipe to retain a first flush event from an 8-acre field and the lower gardens. Stormwater from these areas is collected from a new stormwater system that discharges to the pond.

\section{- Reduces flood-related restoration and clean-up costs by over 95\%, saving an average of $\$ 10,000$ to $\$ 15,000$ annually.}

In the past, following each flood event (an average 2 times per year), Ruth Mott Foundation maintenance staff focused on clean-up operations in the lower garden area. Costs were attributed to removal and replacement of silt-laden aggregate across the gravel path system, cleaning and drying flooring within the two affected structures, and sediment removal from paved surfaces and plant beds. The work was performed principally by staff and the majority of costs were attributed to labor. It is difficult to quantify that actual cost for this since the clean-up is dependent upon the severity of the flooding. The creek restoration project all but eliminated flooding (up to a 500-year flood event) in the lower gardens and no additional clean-up costs are anticipated. The HEC RAS modeling prepared during the design phase of the project verified this flood reduction.

\section{- Restored connectivity to 3 miles of upstream riparian corridor for terrestrial and aquatic species.}

Reflected by field measurements. Prior to the Gilkey Creek Restoration project, the underground portion of Gilkey Creek created a physical barrier along the creek for fish migration and a riparian corridor gap for the migration of terrestrial species commonly observed along riparian habitat. The riparian restoration at Applewood removed this obstruction. Now there is a continuous, unobstructed 3-mile long riparian corridor that starts that the creek confluence with the Flint River upstream to the northern end of the Flint park system. Fish and terrestrial species can now migrate upstream in a natural habit with no physical obstructions such as pipes and roads, which is uncommon in an urban setting. 
- Reduced long-term site maintenance costs by 50\%, an estimated annual savings of $\$ 20,000$, by converting 6.6 acres of pavement and lawn to native landscapes.

This is the result of reduction in labor and materials that the Ruth Mott Foundation horticultural and maintenance staff will realize. Approximately 4 acres of turf area no longer require weekly maintenance by the staff. The annual savings for this work is $\$ 14,000$. The removal of 2 acres of the parking lot accounted for the remainder of the savings. Each year, the savings associated with the maintenance of this surface included $\$ 4,000$ - $\$ 5,000$ for sweeping, pavement sealing, and isle striping.

- Created local employment opportunities by utilizing contractors from the surrounding four-county region for $80 \%$ of work.

Contractor verified. As part of the bidding and award selection, the contractor was required to utilize local labor forces and to provide documentation prior to contract award. While not a prevailing wage rate project, the general contractor hired local labor and retained local subcontractors for trucking, clearing and grubbing, fencing, landscape restoration, and material suppliers for concrete and quarry stone used for creek restoration. 